\title{
SISTEM BAGI HASIL PADA USAHATANI PADI SAWAH DI KECAMATAN LANGOWAN UTARA
}

\section{PROFIT-SHARING SYSTEM IN LOWLAND RICE FARMING AT NORTH LANGOWAN SUB-DISTRICT}

\author{
$\underline{\text { Andre Rolef Bawohan }}^{(1)}$, Theodora Maulina Katiandagho ${ }^{(2)}$, Mex Frans Lodwyk Sondakh ${ }_{-}^{(2)}$
}

1) Mahasiswa Program Studi Agribisnis, Fakultas Pertanian, Universitas Sam Ratulangi, Manado

2) Dosen Program Studi Agribisnis, Fakultas Pertanian, Universitas Sam Ratulangi, Manado *Penulis untuk korespondensi: andreasbawohan1994@gmail.com

Naskah diterima melalui Website Jurnal Ilmiah agrisosioekonomi@unsrat.ac.id

Selasa, 9 Maret 2021

Disetujui diterbitkan

Jumat, 28 Mei 2021

\begin{abstract}
The purpose of this study was to determine the profit sharing system between land owners and tenants in Langowan Utara Sub-District. This research was conducted for three months at Langowan Utara District from November 2020 to January 2021. The data used in this study are primary data which is processed based on interviews with 15 tenant farmer respondents who were taken intentionally and secondary data were obtained from the village office and sub-district office and literature in libraries and on the internet related to this research. The method used in this research is descriptive method. The results showed that the sharing of agricultural land in the village was carried out with a system of three or 1:2, the division was that the tenant farmers got two parts and the owner farmers got one share, the provision of seeds, fertilizers, labor, etc. until the harvest period is borne by the cultivator while the owner farmer only receives the net harvest without paying any fees.
\end{abstract}

Keywords: profit-sharing system; lowland rice; Langowan Utara District; Minahasa Regency

ABSTRAK

Tujuan dari penelitian ini adalah untuk mengetahui sistem bagi hasil antara pemilik lahan dengan petani penggarap yang terjadi di Kecamatan Langowan Utara. Penelitian ini dilaksanakan selama tiga bulan di Kecamatan Langowan Utara dari bulan November 2020 sampai dengan Januari 2021. Data yang digunakan dalam penelitian ini adalah data primer yang diperolah berdasarkan wawancara terhadap 15 responden petani penggarap yang di ambil secara sengaja dan data sekunder diperoleh dari kantor desa dan kantor kecamatan serta literatur yang ada di perpustakaan maupun internet yang terkait dengan penelitian. Dalam Penelitian ini metode yang digunakan adalah metode deskriptif. Hasil penelitian menunjukkan pelaksanaan bagi hasil lahan pertanian di desa penelitian dilakukan dengan sistem bagi tiga atau 1:2, pembagiannya adalah petani penggarap mendapat dua bagian dan petani pemilik mendapatkan satu bagian, penyediaan bibit, pupuk, tenaga kerja dan lainlain sampai dengan masa panen ditanggung oleh penggarap sedangkan petani pemilik hanya menerima bersih hasil panen tanpa mengeluarkan biaya.

Kata Kunci: sistem bagi hasil; padi sawah; Kecamatan Langowan Utara; Kabupaten Minahasa 


\section{PENDAHULUAN}

\section{Latar Belakang}

Pertanian merupakan salah satu bentuk usaha yang dilakukan oleh masyarakat, terutama masyarakat pedesaan dengan memanfatkan sumber daya modal dan sumber daya alam yang ada seperti: tanah dan air. Masyarakat pedesaan yang bekerja di sektor pertanian terbagi dalam beberapa macam status yaitu petani pemilik, buruh tani, petani penyakap (bagi hasil), dan petani penyewa. Pada umumnya petani yang tinggal di Kecamatan Langowan Utara sebagian besar adalah petani penyakap dan fokus penelitian ini adalah petani penyakap yang tidak semua petani di pedesaan memiliki lahan pertanian sendiri. Namun mereka berusaha menggarap lahan milik orang lain dengan sistem bagi hasil atau sebagai petani penyakap.

Dalam perbedaan sistem kepemilikan lahan ini tentunya akan menimbulkan perbedaan dalam penerimaan petani. Selain itu tingkat pendapatan dan tingkat efisiensi pada usahatani mereka juga akan berbeda pula. Bagi hasil merupakan salah satu sarana tolong menolong bagi sesama manusia dalam memenuhi kebutuhan hidupnya. Pihak yang mempunyai lahan menyerahkan lahannya kepada pihak petani atau penggarap untuk diusahakan sebagai lahan yang menghasilkan, sehingga pihak pemilik lahan dapat menikmati dari hasil lahannya, dan petani yang sebelumnya tidak memiliki lahan untuk bercocok tanam juga dapat berusaha serta dapat memperoleh hasil yang sama dari lahan tersebut.

Perjanjian bagi hasil dilakukan atas dasar kemauan bersama antara pemilik lahan dan penggarap, dengan tujuan saling tolongmenolong antara petani, dan perjanjian ini dilakukan secara lisan dan atas dasar saling percaya.

\section{Faktor Produksi Pertanian}

Menurut Soekartawi (2003) Faktor produksi sendiri diartikan sebagai semua pengorbanan yang diberikan kepada tanaman agar tanaman tersebut mampu tumbuh dengan baik dan menghasilkan dengan baik. Faktor produksi memang sangat menentukan besar-kecilnya produksi yang diperoleh.

\section{Modal Dalam Usaha Tani}

Modal dalam usahatani didefinisikan sebagai bentuk kekayaan, baik berupa uang atau barang yang digunakan untuk menghasilkan sesuatu baik secara langsung maupun tidak langsung dalam suatu proses produksi. Menurut Soekartawi (2003) Modal dapat dibagi menjadi dua bagian, yaitu modal tetap (fixed cost) dan modal tidak tetap (variable cost). Modal tetap terdiri atas tanah, bangunan, mesin, dan peralatan pertanian di mana biaya yang dikeluarkan dalam proses produksi tidak habis dalam sekali proses produksi, sedangkan modal tidak tetap terdiri dari benih, pupuk, pestisida dan upah.

\section{Konsep Bagi Hasil}

Sistem bagi hasil merupakan sistem dimana dilakukannya perjanjian atau ikatan bersama di dalam melakukan kegiatan usaha. Di dalam usaha tersebut diperjanjikan adanya pembagian hasil atas keuntungan yang di dapat antara kedua belah pihak atau lebih. Perjanjian bagi hasil adalah suatu bentuk perjanjian antara seseorang yang berhak atas suatu bidang tanah pertanian dan orang lain yang disebut penggarap, berdasarkan perjanjian dimana penggarap diperkenankan mengusahakan tanah yang bersangkutan dengan pembagian hasilnya antara penggarap dan yang berhak atas tanah tersebut menurut imbangan yang telah disetujui bersama, misalnya masing- masing mendapat seperdua atau penggarap mendapatkan sepertiga bagian.

\section{Pengertian Usaha Tani}

Menurut Soekartawi (1995) ilmu yang mempelajari bagaimana seseorang mengalokasikan sumberdaya yang ada secara efektif dan efisien untuk memperoleh keuntungan yang tinggi pada waktu tertentu disebut ilmu usahatani. Dikatakan efektif apabila petani atau produsen dapat mengalokasikan sumberdaya yang mereka miliki sebaik-baiknya dan dikatakan efisien bila pemanfaatan sumberdaya tersebut menghasilkan keluaran (output) yang melebihi masukan (input). 


\section{Usaha Tani Padi Sawah}

Tanaman padi diusahakan pada dua jenis lahan yaitu lahan basah (sawah) dan lahan kering. Padi yang diusahakan pada lahan basah dikenal sebagai padi sawah sedangkan padi yang dibudidayakan pada lahan kering dikenal sebagai padi ladang. Tanaman padi memerlukan curah hujan yang tinggi kurang lebih 1500- $2000 \mathrm{~mm}$ per tahun dengan ketinggian antara 0-1500 mdpl dengan suhu optimal $23^{\circ} \mathrm{C}$ (Pirngadi dan Makarim, 2006).

\section{Rumusan Masalah}

Berdasarkan latar belakang yang telah diuraikan maka yang menjadi rumusan masalah dalam penelitian ini adalah bagaimana sistem bagi hasil antara pemilik lahan dengan petani penggarap yang terjadi di Kecamatan Langowan Utara?

\section{Tujuan Penelitian}

Tujuan dari penelitian ini adalah untuk mengetahui sistem bagi hasil antara pemilik lahan dengan petani penggarap yang terjadi di Kecamatan Langowan Utara.

\section{Manfaat Penelitian}

Manfaat akademik dari penelitian ini adalah untuk mengetahui bagaimana sistem bagi hasil antara pemilik lahan dengan petani penggarap serta memperkaya teori tentang sistem bagi hasil, dan menjadi perbandingan juga bagi peneliti lain untuk melanjutkan penelitian ini.

\section{METODE PENELITIAN}

\section{Waktu dan Tempat Penelitian}

Penentuan lokasi penelitian dilakukan dengan sengaja (Purposive), yaitu Kecamatan Langowan Utara Pertimbangan ditetapkannya Kecamatan tersebut sebagai lokasi penelitian, karena merupakan wilayah penghasil padi selain itu terdapat juga hubungan erat antara pemilik lahan dengan petani penyakap yaitu melalui sistem bagi hasil. Waktu penelitian selama tiga bulan mulai bulan November 2020 sampai Januari 2021.

\section{Metode Pengumpulan Data}

Data yang akan digunakan dalam penelitian ini adalah data primer dan data sekunder. Data primer diperoleh dengan teknik wawancara langsung dengan petani berdasarkan daftar pertanyaan yang telah di susun (kuesioner). Sedangkan data sekunder diperoleh dari instansiinstansi yang terkait dengan penelitian ini.

\section{Metode Pengambilan Sampel \\ Metode pengambilan sampel dalam} penelitian ini adalah metode pengambilan secara sengaja dimana jumlah petani yang akan dijadikan sampel sebanyak 15 petani penggarap yang ditunjuk oleh kepala jaga di Desa Walantakan, Taraitak dan Tempang di kecamatan Langowan Utara. adalah:

\section{Konsep Pengukuran Variabel}

Variabel yang diukur dalam penelitian ini

1. Karakteristik Responden, yaitu:
a) Umur (tahun)
b) Tingkat pendidikan (SD, SMP, SMA, Perguruan Tinggi)
c) Lamanya berusahatani

2. Variabel Pokok

a) Luas lahan sawah yang diusahakan (Ha)

b) Produksi

c) Sistem bagi Hasil

\section{Metode Analisis Data}

Metode analisis data yang digunakan dalam Penelitian ini adalah metode deskriptif. Teknik analisis data yang menggunakan tabel yang mudah di mengerti dan di interpretasikan, serta menyusun dan menyajikan data menjadi informasi yang jelas dimana data yang diperlukan berasal dari hasil jawaban atas pertanyaan yang diajukan kepada responden dalam bentuk kuesioner.

\section{HASIL DAN PEMBAHASAN}

\section{Luas dan Kondisi geografis}

Kecamatan Langowan Utara Kabupaten Minahasa, Provinsi Sulawesi Utara merupakan salah satu dari kecamatan yang ada di Kabupaten Minahasa yang memiliki luas wilayah 11,18 $\mathrm{km}^{2}$, Kecamatan Langowan Utara terdiri dari 8 desa yaitu desa Walantakan, 
Taraitak, Taraitak 1, Toraget, Karumenga, Tempang, Tempang 2 dan Tempang 3. Penelitian ini di lakukan pada tiga desa yaitu Desa Walantakan, Desa Taraitak dan Desa Tempang.

Tabel 1. Luas Lahan Sawah Menurut Desa dan Jenis Pengairan d Kecamatan Langowan Utara, 2019 (Ha)

\begin{tabular}{|c|c|c|c|}
\hline Desa & Irigasi (Ha) & Non Irigasi & Jumlah \\
\hline Walantakan & 6,0 & 0 & 6,0 \\
\hline Taraitak & 80,0 & 0 & 80,0 \\
\hline Taraitak Satu & 79,0 & 0 & 79,0 \\
\hline Toraget & 0 & 0 & 0 \\
\hline Karumenga & 7,0 & 0 & 7,0 \\
\hline Tempang & 26,5 & 0 & 26,5 \\
\hline Tempang Dua & 25,0 & 0 & 25,0 \\
\hline Tempang Tiga & 18,4 & 0 & 18,4 \\
\hline $\begin{array}{c}\text { Langowan } \\
\text { Utara }\end{array}$ & 242,0 & $\mathbf{0}$ & 242,0 \\
\hline
\end{tabular}

\section{Keadaan Penduduk}

Desa Taraitak memiliki jumlah penduduk 934 jiwa, Desa Karumenga memiliki 1438 jiwa, dan desa Tempang memiliki 634 jiwa. Distribusi penduduk menurut jenis kelamin dapat dilihat pada Tabel 2:

Tabel 2. Jumlah Penduduk berdasarkan Jenis kelamin

\begin{tabular}{ccc}
\hline Nama Desa & Laki-laki & Perempuan \\
\hline Walantakan & 733 & 696 \\
Tempang & 355 & 279 \\
Taraitak & 484 & 450 \\
\hline Jumlah & $\mathbf{1 5 7 2}$ & $\mathbf{1 . 4 2 5}$
\end{tabular}

Tabel 2 menunjukkan bahwa jumlah penduduk perempuan di Desa Taraitak lebih sedikit dari pada laki-laki. Jumlah penduduk laki-laki sebanyak 484 orang dan jumlah penduduk perempuan adalah 450 orang, jumlah penduduk perempuan di Desa Walantakan juga lebil sedikit dibandingkan dengan penduduk laki-laki, jumlah penduduk lakilaki adalah 733 orang dan jumlah penduduk perempuan adalah 696, demikian halnya dengan Desa Tempang jumlah penduduk perempuan lebih sedikit dibandingkan dengan jumlah penduduk laki-laki adalah 355 dan jumlah penduduk perempuan adalah 279

Mata pencaharian penduduk di Desa Walantakan, Tempang dan Taraitak sebagian besar adalah petani. Jumlah penduduk berdasarkan mata pencahariannya secara rinci diuraikan pada Tabel 3.
Tabel 3. Jumlah penduduk berdasarkan Jenis Pekerjaan

\begin{tabular}{lccc}
\hline Nama Desa & Petani & Pedagang & PNS \\
\hline Walantakan & 328 & 0 & 27 \\
Tempang & 160 & 25 & 16 \\
Taraitak & 154 & 39 & 34 \\
\hline Jumlah & $\mathbf{6 4 2}$ & $\mathbf{6 4}$ & $\mathbf{7 7}$ \\
\hline
\end{tabular}

Sumber : BPS Kecamatan Langowan Utara

Di ketiga desa tersebut banyak juga terdapat pedagang dan pegawai negeri sipil yang bekerja sebagai tenaga pengajar, juga tenaga medis serta pegawai negeri yang bekeja diperkantoran. Di Desa Taraitak masyarakat dengan mata pencaharian Petani adalah 154 orang, pedagang 39 orang dan PNS 34 orang, di Desa Walantakan masyarakat dengan mata pencaharian Petani adalah 328 orang, pedagang tidak ada dan PNS adalah 27 orang, dan di Desa Tempang masyarakat dengan mata pencaharian Petani adalah 160 orang, pedagang 25 orang dan PNS adalah 16 orang.

\section{Kelompok Umur Responden}

Umur petani responden bervariasi antara petani yang satu dengan yang lainnya. Jumlah petani responden menurut kelompok umur dapat dilihat pada Tabel 4.

Tabel 4. Kelompok umur Responden

\begin{tabular}{ccc}
\hline $\begin{array}{c}\text { Kelompok } \\
\text { Umur }\end{array}$ & $\begin{array}{c}\text { Jumlah } \\
\text { Responden }\end{array}$ & $\begin{array}{c}\text { Presentase } \\
(\mathbf{\%})\end{array}$ \\
\hline $30-40$ & 2 & 13 \\
$41-50$ & 4 & 27 \\
$51-60$ & 6 & 40 \\
$>61$ & 3 & 20 \\
\hline Jumlah & $\mathbf{1 5}$ & $\mathbf{1 0 0}$ \\
\hline
\end{tabular}

Sumber : Data Primer, 2021

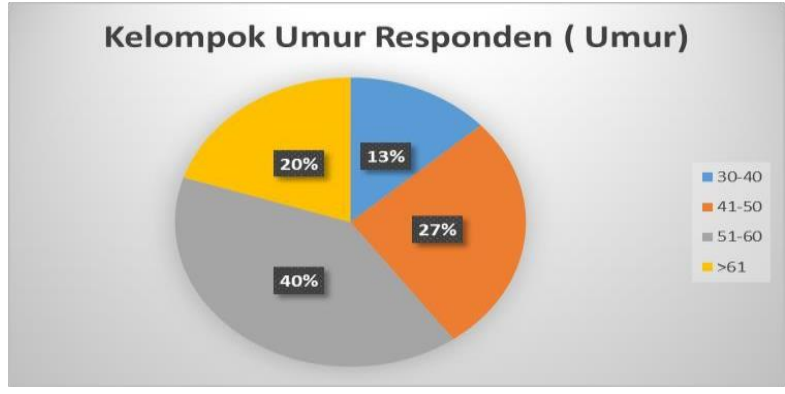

Gambar 1. Kelompok Umur Responden

Dari tabel dan diagram diatas dapat dilihat bahwa dari 15 orang responden kelompok umur 30 tahun sampai 40 tahun sebanyak dua orang petani atau $13 \%$ dari total responden. Untuk kelompok umur 41 tahun sampai 50 tahun 
sebanyak empat orang petani atau $27 \%$ dari total responden, untuk 51 tahun sampai 60 tahun sebanyak enam orang petani atau $40 \%$ dari total responden, dan untuk kelompok umur $>61$ tahun sebanyak tiga orang atau $15 \%$ dari total responden. Hal ini menunjukkan bahwa responden paling banyak adalah berumur 51 sampai 60 tahun.

\section{Tingkat Pendidikan}

Tingkat pendidikan petani berpengaruh pada tingkat penguasaan teknologi budidaya usahatani padi sawah.

\begin{tabular}{lcc} 
Tabel 5. Tingkat Pendidikan & & \\
\hline Tingkat Pendidikan & Responden & Persentase (\%) \\
\hline Tidak tamat SD & 2 & 13 \\
SD & 6 & 40 \\
SMP & 3 & 20 \\
SMA & 3 & 20 \\
S1 & 1 & 7 \\
\hline Jumlah & $\mathbf{1 5}$ & $\mathbf{1 0 0}$
\end{tabular}

Sumber : Data Primer 2021

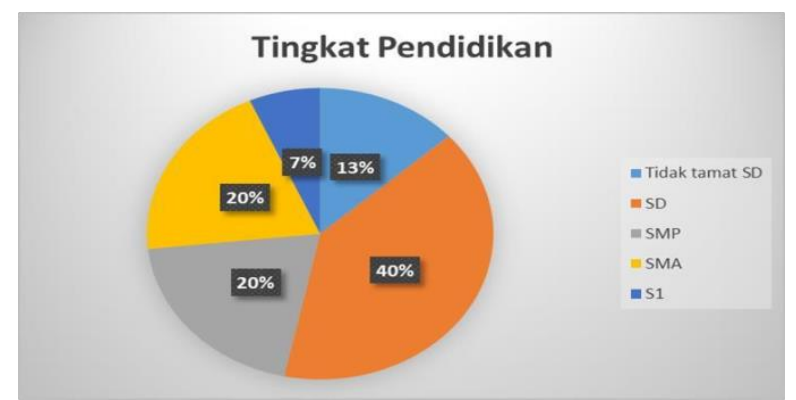

Gambar 2. Tingkat Pendidikan

Dari tabel dan diagram diatas dapat dilihat bahwa tingkat pendidikan responden di ketiga Desa yang berpendidikan S1 adalah paling sedikit, yakni sebanyak satu responden atau $7 \%$. Petani dengan tingkat pendidikan tidak tamat SD adalah sebanyak dua responden atau $13 \%$, petani dengan tingkat pendidikan SD sebanyak enam responden atau $40 \%$, petani dengan tingkat pendidikan SMP sebanyak tiga atau $20 \%$, petani dengan tingkat pendidikan SMA sebanyak tiga responden atau $20 \%$.

\section{Lamanya Berusaha Tani}

Lamanaya berusaha tani yang dimaksud adalah sejak petani mulai menggarap lahan sawah membantu orang tua hingga mampu mengusahakan sendiri usahatani yang dikelolanya.
Tabel 6. Lamanya berusaha tani

\begin{tabular}{ccc}
\hline $\begin{array}{c}\text { Lamanya Berusaha } \\
\text { Tani }\end{array}$ & Responden & Persentase (\%) \\
\hline $5-10$ & 2 & 13 \\
$11-20$ & 8 & 54 \\
$21-30$ & 3 & 20 \\
$>31$ & 2 & 13 \\
\hline Jumlah & $\mathbf{1 5}$ & $\mathbf{1 0 0}$ \\
\hline
\end{tabular}

Sumber : Data Primer 2021

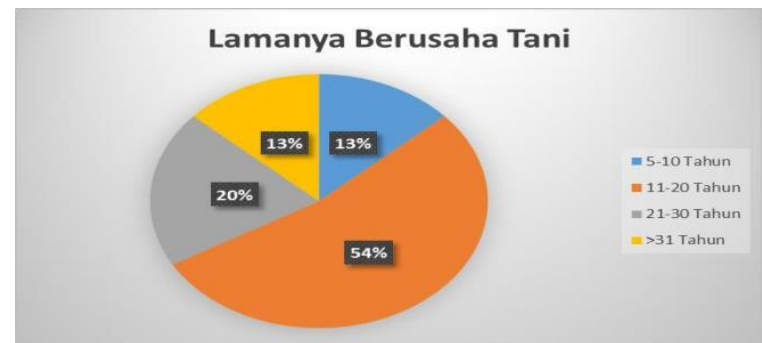

Gambar 3. Lamanya Berusaha Tani

Dari Tabel dan diagram diatas dapat dilihat bahwa respoden dengan lamanya berusaha tani lima tahun sampai 10 tahun sebanyak dua orang petani atau $13 \%$ dari total responden. Untuk 11 tahun sampai 20 tahun sebanyak delapan orang petani atau $54 \%$, untuk 21 tahun sampai 30 tahun sebanyak tiga orang petani atau $20 \%$, dan untuk $>30$ tahun sebanyak dua orang atau $13 \%$ dari total responden.

\section{Bagi Hasil \\ Pemilik Lahan dan Petani Penggarap}

Luas lahan, Produksi dan sistem pembagian di Desa Walantakan, Tempang dan Taraitak dapat dilihat di tabel dibawah ini

\begin{tabular}{|c|c|c|c|c|}
\hline \multirow[t]{2}{*}{ No. } & \multirow{2}{*}{$\begin{array}{l}\text { Luas Lahan } \\
\text { yang } \\
\text { Diusahakan } \\
\text { (Ha) }\end{array}$} & \multirow{2}{*}{$\begin{array}{c}\text { Produksi } \\
\text { (Karung } \\
\text { Gabah) }\end{array}$} & \multicolumn{2}{|c|}{ Pembagian } \\
\hline & & & $\begin{array}{c}\text { Pemilik } \\
\text { (Karung } \\
\text { Gabah) }\end{array}$ & $\begin{array}{c}\text { Penggarap } \\
\text { (Karung } \\
\text { Gabah) }\end{array}$ \\
\hline 1 & 1 & 50 & 17.5 & 32.5 \\
\hline 2 & 0,4 & 21 & 7 & 14 \\
\hline 3 & 0,5 & 26 & 8 & 18 \\
\hline 4 & 0,4 & 21 & 7 & 14 \\
\hline 5 & 0,4 & 21 & 7 & 14 \\
\hline 6 & 1 & 54 & 18 & 36 \\
\hline 7 & 0,3 & 15 & 5 & 10 \\
\hline 8 & 1 & 52 & 18 & 35 \\
\hline 9 & 0,3 & 16 & 5 & 11 \\
\hline 10 & 0,5 & 24 & 8 & 16 \\
\hline 11 & 0,3 & 17 & 6 & 11 \\
\hline 12 & 0,5 & 26 & 9 & 17 \\
\hline 13 & 1 & 49 & 16 & 33 \\
\hline 14 & 0,5 & 27 & 9 & 18 \\
\hline 15 & 0,5 & 27 & 9 & 18 \\
\hline
\end{tabular}


Dari tabel diatas dapat dilihat bahwa lahan yang diusahakan berbeda-beda setiap responden mulai dari luas lahan dan produksi di setiap desa yang menjadi tempat penelitian yaitu desa Walantakan, Taraitak dan Tempang, ada beberapa luas lahan sama yang mereka kerjakan, tapi dalam hasil produksi yang mereka dapat berbeda-beda, tapi ada juga yang sama produksinya, dan berdasarkan hasil wawancara berapun yang mereka dapat pada masa panen pembagianya harus sesuai dengan pembicaraan yaitu hasil panen yang di dapat dibagi tiga atau $1: 2$, dalam bentuk gabah.

Seperti apa yang diceritakan responden penggarap yaitu luas lahan yang dia tanamkan ada sekitaran satu hektar, dengan biaya tanam sampai panen di tanggungnya sendiri, hasil panen yang dia dapat di luas lahan satu hektar hanya 50 karung gabah dan seharusnya lebih dari itu, akan tetapi dengan hasil yang dia dapatkan itu menurutnya tidak merugikan, dalam pembagian 50 karung yang di dapatkan dari hasil panen di bagi tiga, dengan pembagian pemilik mendapat satu bagian dan penggarap mendapat dua bagian, jadi untuk pembagian 50 karung gabah yang di panen dari satu hektar untuk pemilik lahan mendapatkan $(17,5)$ karung gabah dan petani penggarap mendapatkan $(32,5)$.

\section{Sistem Bagi Hasil}

Dari hasil penelitian yang di lakukan di desa Walantakan, Taraitak dan Tempang, sebagian besar petani yang ada di Desa tersebut, dalam melakukan perjanjian sistem bagi hasil hanya dalam bentuk lisan antara pemilik lahan dan petani penggarap tanpa ada perjanjian dalam bentuk tertulis. Bentuk perjanjian sistem bagi hasil pertanian di Desa Walantakan, Taraitak dan Tempang dilakukan secara lisan didasarkan pada rasa saling percaya dan rasa kekeluargaan dari masing- masing pihak, baik pemilik tanah maupun penggarap sawah, perjanjian tersebut hanya didasarkan pada kata sepakat antara kedua belah pihak yaitu penggarap sawah dan pemilik sawah. menurut petani-petani yang ada di Desa Walantakan, Taraitak dan Tempang perjanjian tersebut sudah dianggap sah dan hanya tinggal melaksanakannya saja. dari hasil wawancara juga sebagian dari responden antara pemilik lahan dan petani penggarap memiliki ikatan keluarga tapi ada juga yang hanya sekedar kenalan atau tinggal di Desa yang sama.

Sistem bagi hasil telah lama dilakukan oleh petani-petani yang ada di Desa Walantakan, Taraitak dan Tempang. Pelaksanaan bagi hasil terhadap lahan pertanian padi sawah didasarkan kepada kebiasaankebiasaan yang telah ada. Pelaksanaan bagi hasil lahan pertanian di Desa penelitian dilakukan dengan sistem bagi tiga atau 1:2, pembagiannya adalah petani penggarap mendapat dua bagian dan petani pemilik mendapatkan satu bagian. karena dengan hasil penelitian tersebut, kebanyakan petani penggarap yang ada di desa Walantakan, Taraitak dan Tempang, untuk biaya pertanian tersebut di tanggung semua oleh penggarap, mulai dari penyediaan bibit, pupuk, tenaga kerja dan lain-lain sampai dengan masa panen sedangkan petani pemilik hanya menerimah bersih hasil panen tanpa mengeluarkan biaya, hanya saja pemilik lahan meminjamkan lahannya untuk di kerjakan atau dengan bahasa petani ditempat penelitian dengan istilah (batoyo).

Dari hasil penelitian yang didapatkan dari data dan informasi di lapangan dengan cara wawancara terhadap petani penggarap sawah mengenai pelaksanaan sistem bagi hasil pertanian padi sawah di Kecamatan Langowan Utara yang di dalamnya Desa Walantakan, Taraitak dan Tempang. Perjanjian bagi hasil terhadap pertanian padi sawah sudah dilakukan sejak lama oleh petani penggarap dan pemilik lahan yang ada di Desa Walantakan, Taraitak dan Tempang, hal ini terjadi disebabkan karena pemilik lahan tidak dapat mengolah sawahnya sendiri, kemudian pemilik menawarkan kepada orang lain yang bersedia mengolah lahannya dengan cara bagi hasil. Tetapi ada juga pihak penggarap yang sengaja meminta kepada pemilik sawah agar memberi ijin untuk menggarap lahan pertaniannya. Seperti halnya yang di katakan oleh responden di tempat penelitian awal mulanya pembicaraan petani penggarap dan pemilik lahan, pertama hanya sekedar berbincang tentang pembicaraan lahan pertanian yang di miliki oleh pemilik lahan, 
dan dikarenakan pembicaraan mulai panjang dan ternyata pemilik lahan tersebut, sudah tidak mampu untuk mengerjakan lahanya sendiri dan terjadilah perbincangan antara petani penggarap dan pemilik lahan, ternyata pemilik lahan ingin menggarabkan lahan pertaniannya atau di kerjakan, maka terjadilah pembicaraan serius di mana pemilik lahan meminta untuk lahannya di kerjakan dan di terimah oleh penggarap, maka terjadinyalah pembicaraan tentang sistem bagi hasilnya, dan menurut petani penggarap dalam pembicaraan mereka, penggarap akan suka menggerjakan lahan pemilik asalkan sistem bagi hasilnya harus di bagi tiga atau disebut 1:2, dimana pemilik mendapat satu bagian dan penggarap mendapat dua bagian karena biaya bibit, pupuk, obat-obatan dan lain- lain ditanggung oleh penggarap dan pemilik pun menerima pembagian dari penggarap.

Pembagian yang biasa juga di lakukan petani penggarap dan pemilik lahan di tempat peneliti, pembagianya bukan di hitung dari berapa $(\mathrm{kg})$ yang di panen lalu di bagikan, tatapi mereka terbiasa dengan pembagianya di hitung per karung, dengan berapa hasil yang di dapatkan pada masa panen, setiap masa panen petani penggarap langsung menyerahkan hasil panen padi gabah kepada pemilik lahan dengan sistem bagi hasil yang sudah di sepakati kedua pihak, jadi petani penggarap dan pemilik lahan yang ada di Desa Walantakan, Taraitak dan Tempang Kecamatan Langowan Utara, sudah terbiasa dengan pembagian yang masih gabah. Tetapi juga resiko petani penggarap sangatlah besar jika terjadi hal-hal yang tidak di inginkan dalam tahap pertanian, seperti diserang hama yang menyebabkan gagal panen sehingga hasilnya tidak sesuai dengan yang di harapkan. Atau padi tidak menghasilkan gabah yang berkualitas baik atau biasa di sebut petani (pesel). Sehingga kerugiannya ditanggung oleh petani penggarap.

Pada dasarnya konflik antara pemilik dan penggarap sawah tidak pernah terjadi dalam pelaksanaan bagi hasil ini. Hal ini dikarenakan pihak pemilik maupun pihak penggarap memiliki hubungan yang saling membutuhkan serta rasa saling percaya antara satu dengan yang lain. Kedua belah pihak sama-sama berusaha menjaga hubungan baik, sehingga kerjasama bagi hasil tersebut bisa berlangsung lama. Setelah perjanjian bagi hasil ini usai, maka pihak penggarap wajib menyerahkan kembali tanah pertanian yang bersangkutan kepada pemilik dalam keadaan baik. Setelah itu, pemilik dapat melakukan perjanjian bagi hasil dengan orang lain yang belum mempunyai garapan.

\section{KESIMPULAN DAN SARAN}

\section{Kesimpulan}

Berdasarkan hasil penelitian dan pembahasan maka penulis menarik kesimpulan bahwa:

1. Pelaksanaan bagi hasil di tempat penelitian dilakukan dengan sistem bagi tiga atau 1:2, pembagiannya adalah petani penggarap mendapat dua bagian dan petani pemilik mendapatkan satu bagian Perjanjian sistem bagi hasil hanya dalam bentuk lisan antara pemilik lahan dan petani penggarap tanpa ada perjanjian dalam bentuk tertulis.

2. Pembagian 50 karung gabah yang di panen dari satu hektar untuk pemilik lahan mendapatkan $(17,5)$ karung gabah dan petani penggarap mendapatkan $(32,5)$, ternyata untuk biaya pertanian tersebut di tanggung semua oleh penggarap, mulai dari penyediaan bibit, pupuk, tenaga kerja dan lain-lain sampai dengan masa panen sedangkan petani pemilik hanya menerimah bersih hasil panen tanpa mengeluarkan biaya, Pembagian yang biasa juga di lakukan petani penggarap dan pemilik lahan di tempat peneliti, pembagianya bukan di hitung dari berapa $(\mathrm{kg})$ yang di panen lalu di bagikan, tatapi mereka terbiasa dengan pembagianya di hitung per karung, dengan berapa hasil yang di dapatkan pada masa panen, setiap masa panen petani penggarap langsung menyerahkan hasil panen padi gabah kepada pemilik lahan dengan sistem bagi hasil yang sudah di sepakati kedua pihak.

\section{Saran}

Penulis menyarankan agar dalam setiap melakukan suatu bentuk kerja sama dengan sistem bagi hasil sebaiknya dilakukan dalam bentuk tertulis sehingga jika terjadi hal yang tidak diinginkan ada perjanjiannya. 
DAFTAR PUSTAKA

Anonim, UU RI No 2 Tahun 1960 tentang Perjanjian Bagi Hasil.

Badan Pusat Statistik (BPS) Kecamatan Langowan Utara Dalam Angka Tahun 2019

Pirngadi, K. dan A.K. Makarim.2006. Peningkatan Produktivitas Padi pada Lahan Sawah Tadah Hujan melalui Pengelolaan Tanaman Terpadu. Penelitian Pertanian Tanaman Pangan, Vol. 25 (2):116-123. Puslitbangtan, Bogor.
Soekartawi. 2003. Teori Ekonomi Produksi dengan Pokok Bahasan Analisis CobbDouglas. Jakarta: PT Raja Grafindo Persada. 250 hal.

Soekartawi. (1995). Analisis Usahatani. Jakarta: UI-PRES 